\title{
Mathematics Conceptions by Teachers from an Ethnomathematical Perspective
}

\author{
Concepciones sobre las matemáticas de los profesores desde una \\ Perspectiva Etnomatemática
}

\author{
Veronica Albanese \\ ORCID iD 0000-0002-3176-2468 \\ Francisco Javier Perales ${ }^{* *}$ \\ ORCID iD 0000-0002-6112-2779
}

\begin{abstract}
The ethnomathematical perspective implies substantial epistemological changes in mathematics conception with respect to the positivist tradition. This research focuses on a workshop for pre-service teachers, designed and developed under the ethnomathematical perspective, and which promotes reflection on the nature of mathematical knowledge. To that end, we analyzed the teachers' answers about the nature of the mathematics described after the participation in this workshop. First, we identified some characteristic approaches of mathematics from the ethnomathematical perspective - the practical, social, and cultural approaches - and then used them to analyze the participants' observations, which are considered as evidence of their conceptions about the nature of mathematical knowledge. Later, we grouped participants in profiles defined in relation to the incorporation of mathematics approaches according to Ethnomathematics. In conclusion, the workshop is shown as an environment conducive to reflection.
\end{abstract}

Keywords: Beliefs. Conceptions. Mathematics. Teacher Education. Ethnomathematics.

\section{Resumen}

La perspectiva etnomatemática implica cambios epistemológicos sustanciales en la concepción de las matemáticas, respecto a la tradición positivista. En esta investigación nos centramos sobre un taller diseñado y desarrollado bajo la perspectiva etnomatemática para profesores en formación y en activo, analizando sus observaciones relacionadas con las concepciones sobre la naturaleza de las matemáticas, que manifiestan tras la participación en dicho taller. Para ello, identificamos unos enfoques característicos de la Etnomatemática y los utilizamos para analizar las observaciones de los participantes, las cuales consideramos como evidencia de sus concepciones. Posteriormente, agrupamos a los participantes en perfiles establecidos en relación a su mayor o menor acercamiento a los enfoques propuestos desde la Etnomatemática. En conclusión, el taller se muestra como un entorno propicio para la reflexión.

Palabras clave: Creencias. Concepciones. Matemáticas. Formación docente. Etnomatemática.

\footnotetext{
* Doctora en Educación por la Universidad de Granada (UGR). Investigadora y Profesora Contratada Doctora en Didáctica de la Matemática en la Universidad de Granada (UGR), Melilla, España. Dirección postal: Calle Santander, 1, 52005, Melilla, España. E-mail: vealbanese@ugr.es.

** Doctor en Física por la Universidad de Granada (UGR). Investigador y Profesor Catedrático de Didáctica de la Ciencias Experimentales en la Universidad de Granada (UGR), Granada, España. Dirección postal: Campus Universitario de Cartuja s/n, 18071, Granada, España. E-mail: fperales@ugr.es.
} 


\section{Introduction}

Ethnomathematics has its roots in anthropological studies on the mathematics of indigenous people and it was created to recognize and describe the ideas and practices of different cultural groups, indigenous people, guilds, and communities (D’AMBROSIO, 1985; BARTON, 1996). Later on, in order to give meaning to the confrontation of different ethnomathematical perspectives, its purpose extended to a broader relativistic view of mathematical knowledge in relation to its development in different cultures (ALBANESE; ADAMUZ-POVEDANO; BRACHO-LOPEZ, 2017). Furthermore, this was done to explain why and how diverse individuals reveal different interests, talents, skills, and strategies to generate, organize, and share such knowledge. This new perspective draws on the contributions of diverse disciplines that share a relativistic stance (ALBANESE; PERALES, 2014).

In Albanese, Adamuz-Povedano and Bracho-López (2017), two aspects are identified among the educational implications of Ethnomathematics: the first deals with the development of activities or experiences, in general in formal education settings, that bring school mathematics closer to the knowledge acquired outside school in the social and cultural environment; the second deals with the development of workshops in preservice or in-service teacher education for reflection on the nature of mathematical knowledge from a sociocultural perspective, with the ultimate aim of modifying the teaching practice through changes in the teachers' beliefs or conceptions.

This document attempts to contribute to this second aspect, that is, through a workshop on the modelling of a craft practice. The aim is to bring to the surface some mathematics conceptions that are framed within the socio-cultural perspective, as well as proposing a model for the interpretation of conceptions that takes into account socio-cultural nuances from an ethnomathematical perspective.

\subsection{Background}

Due to the epistemological changes involved in ethnomathematics, there have been seminars, courses, and workshops out for teacher education with the common objective of raising awareness, among teachers, on the nature of mathematics as a social and cultural product. Some examples are:

Oliveras (1996) used microprojects on Andalusian handicrafts in early teacher training 
courses to raise awareness about their conceptions on the nature of mathematical knowledge, producing changes in their mathematics conceptions and their learning environments.

In addition, Gerdes (1998) reflected on the need to raise awareness about the social and cultural bases of mathematics in teacher training. In the Mozambican context, it pointed to the importance of future teachers learning to recognize the mathematical roots in their own and in other African cultures.

Whereas, Presmeg (1998) focused on the above points in his courses for future US teachers, leading them to affirm, value, and take advantage of the points of view concerning cultural diversity and the relation of mathematics to social reality in their professional lives.

More recently, Gavarrete (2012), in a course with indigenous Costa Rican teachers, promoted relativistic conceptions about mathematics that integrate traditional academic knowledge with indigenous cultural knowledge.

Naresh (2015) mentioned a transforming learning experience during a Phd course where she embrace a culturally relevant conception of what mathematics is.

Finally, Nolan and Graham (2018) challenged the teachers' perception of what mathematics is during a course on cultural-responsive pedagogy.

But even though all of this authors suggest a direct or indirect influence on the participants' epistemological conceptions, they do not present a structured analysis of this influence, that is why we present the following proposal of approaches and related categories as innovative.

\subsection{Objective}

Following the precedent set by these authors, a workshop was developed for preservice teachers at the University of Buenos Aires as part of a broader Phd project of the first author. The workshop had the purpose of fostering participants' reflections mainly about the social and cultural aspects on the nature of mathematical knowledge.

The objective of this research is to describe and analyze their conceptions about the nature of mathematics after the proposed workshop.

For this, we identified some approaches that are characteristic of the ethnomathematical perspective which were used later to analyze the participants' conceptions. These approaches took shape during a complex process, partly inductive from the data analysis and partly deductive, deepening the study of the theoretical contributions made by some prominent researchers of ethnomathematics. Finally, we grouped the participants into 
profiles according to the incorporation of the above-mentioned approaches.

\section{Theoretical Framework}

In scientific literature, there are many studies about conceptions, even though this term is not uniquely defined and there is some similarity with the term beliefs. Pajares (1992) and Ponte and Chapman (2006) distinguish conceptions from beliefs stating that beliefs are personal truths derived from experience or fantasy, without internal consistency, with an affective and valuative connotation, while conceptions are organizing structures that underlie concepts and have a cognitive connotation. As we insist on the cognitive connotation, we prefer the term conception.

It is considered that conceptions play an important role in guiding people's actions and influence the teacher's classroom practice (ERNEST, 1989; and see the review of FELBRICH; KAISER; SCHMOTZ, 2014). As Liljedahl, Oesterle and Bernèche's (2012) review suggests, conceptions are a relatively stable construct, and influencing it to produce a change requires a difficult and/or slow process, although they are a construct that is constantly evolving in each individual. Cooney (2001) states that for there to be a change in conceptions, we need two components: doubt and experience.

In this research, we will not pretend to affirm that there is a change in the participants' conceptions, but only aim to show that Ethnomathematics contributes on providing: 1) a favorable environment for the reflection on what is mathematics, 2) sociocultural nuances to the theoretical models of conceptions on the nature of mathematics.

Researchers (ERNEST, 1989; GOLDIN; RÖSKEN; TÖRNER, 2009; PAJARES, 1992) usually distinguish among conceptions on the nature of mathematics, on teaching mathematics, and on learning mathematics. The focus of this research is on the former. Like Presmeg (2002, p. 293-294) we will use the term conceptions on the nature of mathematics to indicate what participants write and state about what mathematics is or what doing mathematics is about, in other words, the epistemological nature of mathematics.

In the literature, there have been different models but related to the conceptions on the nature of mathematics (Frame 1).

\begin{tabular}{|l|l|l|l|l|}
\hline \multicolumn{1}{|c|}{ Dionne (1984) } & \multicolumn{1}{|c|}{ Ernest (1989) } & $\begin{array}{c}\text { Törner \& Grigutsch } \\
(\mathbf{1 9 9 4 )}\end{array}$ & \multicolumn{2}{|c|}{ Grigutsch, Raatz \& Törner (1998) } \\
\hline $\begin{array}{l}\text { Formalist } \\
\text { perspective }\end{array}$ & Platonist view & System Aspects & $\begin{array}{l}\text { Formalism- } \\
\text { Related } \\
\text { Orientation }\end{array}$ & Static View \\
\cline { 1 - 4 } Traditional & Instrumentalist & Toolbox Aspects & Scheme-Related & \\
\hline
\end{tabular}




\begin{tabular}{|c|c|c|c|c|}
\hline perspective & view & & Orientation & \\
\hline \multirow[b]{2}{*}{$\begin{array}{l}\text { Constructivism } \\
\text { perspective }\end{array}$} & \multirow[b]{2}{*}{$\begin{array}{l}\text { Problem Solving } \\
\text { view }\end{array}$} & \multirow[b]{2}{*}{ Process Aspects } & $\begin{array}{l}\text { Process-Related } \\
\text { Orientation }\end{array}$ & \multirow[b]{2}{*}{ Dynamic View } \\
\hline & & & $\begin{array}{l}\text { Application- } \\
\text { Related } \\
\text { Orientation }\end{array}$ & \\
\hline
\end{tabular}

Frame 1 - Models of conceptions about the nature of mathematics used in the literature Source: Elaborated by the authors.

Many researchers (LILJEDAHL; ROLKA; ROESKEN, 2007; CROSS, 2009; CHARALAMBOUS; PANAOURA; PHILIPPOU, 2009) used one of them or a combination of the first three proposals (DIONNE, 1984; ERNEST, 1989; TÖRNER; GRIGUTSCH, 1994), where a distinction is made between three categories: a) the formalist-Platonist-system view sees mathematics as a static unified body of knowledge characterized by logic and rigorous proofs and exacts definitions; b) the traditional-instrumentalist-toolbox view sees mathematics as an organized set of instruments with a set of skills, formulas, rules, and procedures; c) the constructivism-problem solving-process view sees mathematics as a product of a constructive process in a dynamic and continuous evolution used to solve reallife problems.

The last proposal of Grigutsch, Raatz and Törner (1998, more recently used by FELBRICH; MÜLLER; BLÖMEKE, 2008; FELBRICH; KAISER; SCHMOTZ, 2014), establishes that conceptions on the nature of mathematics can be grouped in a dichotomic view as static-oriented and dynamic-oriented. The static view includes formalism-related orientation and the (rigid) scheme-related orientation, where mathematics is considered as an exact, axiomatic science, and as a collection of terms, procedures, and formulas, respectively. The dynamic view includes process-related orientation and application-related orientation, where mathematics is seen as a science that involves problem-solving and the discovery of structure and regularities, and as a science that is useful for society and life, respectively.

In this work, we are not interested in the static view of mathematics. In the following sections, we will define some approaches that we propose for the nature of mathematics in an ethnomathematical perspective: the practical approach, the social approach and the cultural approach. The practical approach is close to the dynamic view of mathematics mentioned above, while we can consider the social and cultural approach as a culturally based dynamic view of mathematics.

The approaches we identify are related to the well-known six dimensions of Ethnomathematics described by D'Ambrosio (2008), namely the cognitive, conceptual, political, epistemological, historical dimensions, and transversely to the educational dimension, and we will make this relation explicit in the following sections. It should be 
noted that these approaches are closely interconnected and their separation is done only in order to handle them when designing the experience described here and for analyzing the data.

\subsection{Practical Approach}

D'Ambrosio's definition of ethnomathematics (2008) as the styles, arts, and techniques (Ticas) of explaining, understanding, managing, and connecting with (Matema) the natural and social environment (Ethno), points to mathematical knowledge as an instrument for understanding and managing reality. Such knowledge develops as a consequence of the need to make decisions and arises from representations and reality models that relate to the perception of time and space. Then, mathematics is a way of knowledge used to act in the context that surrounds us for controlling it and eventually modifying it.

In this practical approach, elements of the conceptual and cognitive dimensions of D'Ambrosio (2008) converge, referring to mathematics respectively as an instrument to represent and model reality, and as organizational structures of experience.

Regarding the educational context, this practical approach implies developing the relation of mathematics with reality, valuing its origin in concrete practices of daily life, as well as its use for environment manipulation. Methodologically, direct experience and research are promoted (D'AMBROSIO, 2008), as well as experiencing mathematical attitudes, contact, and participation in mathematical inquiry (OLIVERAS, 1996; PRESMEG, 1998) to develop skills critical to the environment. These considerations are widely recognized when speaking of sciences in general, but hardly accepted when it comes to mathematics.

\subsection{Social Approach}

Barton (2012) proposes to interpret mathematics as a system of meanings through which a group of people gives meaning to quantity, relationships, and space. Communities that share a common vision of reality and agree on common codes build these systems. This perspective assesses the importance of language that allows communication within the group and is based on the theoretical reflections of Barton (2012) and Knijnik (2012). These authors coincide in referencing Wittgenstein and his language games as a key philosopher to look at mathematics as a system, as a socially-shared language which exploration has to focus on its 
operation and use.

In this social approach, elements of the political dimension of D'Ambrosio (2008) also come into play given that factors of power affect communication and the achievement of consensus.

The implications for the educational context are linked to social constructivism, that is, to a methodology that values the construction of knowledge with work in small groups, reaching agreement on a shared interpretation of experiences (OLIVERAS, 1996; PRESMEG, 1998).

\subsection{Cultural Approach}

Ethnomathematics establishes a deep relationship between mathematics and culture. If the location of mathematics is the collective mind of the human species, the origin of mathematics is situated in culture, the body of behavior and thought of mankind (WHITE, 1988 quoted in GAVARRETE, 2012).

A key element of this position is the assumption that there are several mathematics and their differences depend precisely on the different cultures in which they are constituted. From the philosophical perspective, it is accepted as a form of relativism that allows the coexistence of different mathematics. D'Ambrosio (2008) argues mainly for a historical vision, meaning that it admits an evolution of mathematics due to the development in the time of cultures. However, Barton (2012) insists on the need of philosophically justifying that there are different mathematics simultaneously, which are not subordinate to each other, meaning that there is no development hierarchy between them.

Therefore, in this cultural approach, D'Ambrosio's (2008) historical dimension - with the clarifications of the previous paragraph - and D'Ambrosio's (2008) epistemological dimension come together.

For the educational context, these reflections lead to proposals of working with cultural groups that maintain different visions of mathematics, addressing the variety of their contents, thoughts, and contributions (SHIRLEY, 2001). In this context, the aspects of our own cultural background or of a culture close to the student are investigated (BISHOP, 1999; GAVARRETE, 2012; OLIVERAS, 1996). As far as fieldwork is concerned, the importance of learning about sociocultural factors is highlighted - context, relationships, needs (GERDES, 1998). 


\section{Research Methods}

\subsection{Geographical Context}

The research geographical context is the city of Buenos Aires, which was selected for two reasons: 1) the workshop focuses on Argentinean braids crafts, and 2) the Argentinean legislative guidelines in the educational field are based on principles that are shared with ethnomathematics (ALBANESE; SANTILLÁN; OLIVERAS, 2014).

Argentina is a country deeply linked to its country tradition. Likewise, the country has shown great interest in valuing its cultural heritage and folklore (DE GUARDIA, 2013) through educational actions as well. The handicraft chosen has great cultural significance for its diffuse use in the northern and central regions where the braids are used to work with animals and in characteristic decorations (ALBANESE; OLIVERAS; PERALES, 2014).

\subsection{The Workshop}

The workshop that we carried out followed the line proposed by Oliveras (1996), which deals with the study of a cultural feature - a trait or element of a determined culture or microculture that contains some mathematical potential, to later design mathematical tasks and the idea of investigating the mathematics enclosed in the ethno-modeling of reality done by cultural groups (ROSA; OREY, 2012).

The cultural feature that we chose was a handicraft from the region of Salta, Argentina; the mathematics enclosed in these ethnomodels has been investigated in previous research (ALBANESE; OLIVERAS; PERALES, 2014). The ethnographic research in the artisanal environment has provided a mathematical ethnomodel of braiding that presents great possibilities for its educational use (OLIVERAS; ALBANESE, 2012).

The workshop is designed as a session of a pre-service teachers' course, and was validated with a previous pilot experience. Specifically, this took place in June 2013, in two four-hour sessions each. There was a group of 14 participants from the optional course "Workshop of Mathematical Modeling and Production" in the Mathematics Teachers degree at the University of Buenos Aires. Here we present a brief description of the workshop, but a more detailed one can be found in Albanese and Perales (2017).

In the workshop, we used an investigative methodology, where the participants constructed and agreed on a creative modeling for the making of a simple four-wire braid that 
involves the construction of the mathematical concept in an oriented graph. In a later moment, participants worked with the model created and used by the artisans (the ethnomodel). The course teachers acted spontaneously as guides and mediators in the debates.

The workshop was organized in three stages (see Frame 2 below): (A) initial debate with presentation of ethnomathematics through the sharing of observations on selected fragments of several authors previously read by the participants (BARTON, 1996; BISHOP, 1999; D'AMBROSIO, 2008; GERDES, 1998); (B) representation and elaboration of braids; (C) final debate about the work done and answers to an open questionnaire on the work's epistemological implications (such questions are detailed below in paragraph 4.3). The central stage (B), focused on the craft activity, was composed of four phases.

\begin{tabular}{|c|c|}
\hline Stage & Phase \\
\hline $\begin{array}{l}\text { (A) Presentation of } \\
\text { Ethnomathematics and } \\
\text { initial debate }\end{array}$ & $\begin{array}{l}\text { Reading and discussion of selected definitions of } \\
\text { Ethnomathematics in comparison with personal previous } \\
\text { opinions. }\end{array}$ \\
\hline \multirow{4}{*}{$\begin{array}{l}\text { (B) Representation and } \\
\text { elaboration of braids }\end{array}$} & 1. Description of the braid-making process: individual. \\
\hline & $\begin{array}{l}\text { 2. Development of a shared creative representation: in small } \\
\text { groups. }\end{array}$ \\
\hline & $\begin{array}{l}\text { 3. Presentation of the representations and artisanal modeling: } \\
\text { interaction among groups. }\end{array}$ \\
\hline & $\begin{array}{l}\text { 4. Discovery of eight-wire braid patterns to develop those for the } \\
\text { 16-wire ones: full group and individual interactions. }\end{array}$ \\
\hline $\begin{array}{l}\text { (C) Final debate and } \\
\text { answers to the } \\
\text { questionnaire }\end{array}$ & $\begin{array}{l}\text { Written and oral discussion about the workshop's } \\
\text { epistemological implications. }\end{array}$ \\
\hline
\end{tabular}

Frame 2 - Stages and phases of the workshop.

Source: Albanese and Perales (2017, p. 78).

Each phase was characterized by a different interaction between participants:

Phase 1: Participants were provided with the necessary tools for braiding. Then, they were asked to individually describe the process; first graphically-ironically and then with words.

Phase 2: A creative representation was made aimed at the construction of a model. That is, from the individual description previously made, the participants reach a consensus within the group on an iconic and then a symbolic representation that synthesizes and describes the process of braiding.

Phase 3: In the sharing of the agreed representations, the participants reflect on the decisions made by each group (advantages and limitations). Finally, the artisanal four-wire braiding modeling that involves the mathematical concept of an oriented graph was presented (first graph in Figure 1). 
Phase 4: the participants were offered a handmade modeling of three eight-wire braids (last three graphs in Figure 1). Pattern recognition in the graphs that represented them allowed the participants to later create graphs of 16-wire braids.
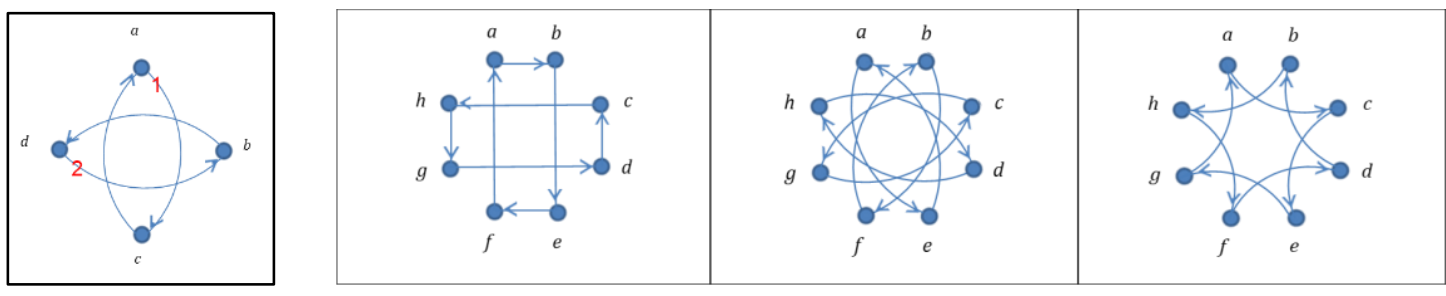

Figure 1 - Oriented graphs modelling four and eight-wire braids. Source: Albanese, Oliveras and Perales (2012).

The approaches mentioned above were reflected in the phases. Since conceptions are formed through experience (COONEY, 2001), participants experienced the practical, social, and cultural approaches. Phases 1 and 4 emphasized the practical approach of mathematics as a tool for understanding reality and organizing experiences. In Phase 2, emphasis was placed on the social approach of consensus and sharing of mathematical productions within the community. Whereas in Phase 3, the cultural approach was emphasized in the different ways of thinking mathematically and the artisan culture being recognized as a culture creating knowledge.

\subsection{Focus of Research}

The research is an exploratory study presented in a qualitative framework due to the affinity of this methodology with the ethnomathematical purposes, as well as for the interest of investigating people's conceptions in the educational context (WOODS, 1987).

\subsection{Data collection tools}

The data were collected through audiovisual recordings, transcripts, field notes of the researcher who runs the activity, evaluation sheets of the two course teachers, worksheets of all participants, and the open questionnaire. This variety of data, characteristic of a qualitative research, is fundamental to ensure triangulation and, therefore, research validity.

We performed a data qualitative content analysis (CABRERA, 2009) with the support of the program MAXQDA7, and we show below the results of the debates transcripts and the answers to the final questionnaire.

Descriptive codes are inductive. The higher order categories that group codes 
determined by practical, social, and cultural approaches were obtained through an inductivedeductive cyclical process. Their observation and first outline emerged during a pre-analysis or speculative analysis (WOODS, 1987), and its refinement was contrasted to the theoretical foundations mentioned above which were also organized according to these approaches.

We initially hypothesized a strong presence of the practical category, then an intermediate presence of the social category and finally a minor presence of the cultural category, as a sign of a progression in the reflection process about the sociocultural characterization of mathematics.

\section{Results analysis}

We describe here the results of the initial oral debate (Stage A, Frame 2), the final oral debate and, in more detail, the written responses to the final questionnaire (Stage C, Frame 2). In the analysis, we focused on aspects related to the approaches of the conceptions defined in the theoretical framework, now referred to as practical, social, and cultural categories.

\subsection{Initial debate}

Figure 2 shows the results of the initial shared analysis with the observations made after the readings on ethnomathematics. The participants' codes preserve their anonymity.

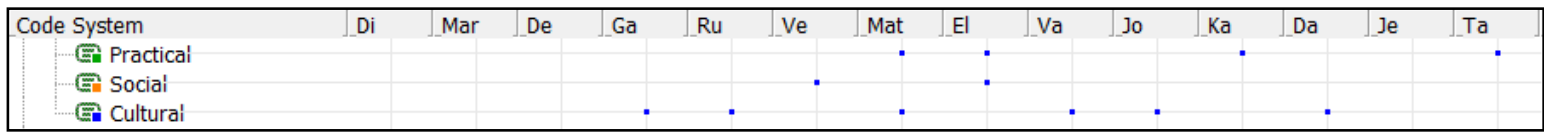

Figure 2 - Code matrix generated by MAXQDA7 for the initial debate. The rows represent practical-socialcultural categories and the columns the participants (those without marks did not intervene).

Source: Elaborated by the authors.

Six participants acknowledged as ethnomathematics studies the different mathematics that arise in culture (cultural category), but all referred to the proposed text without expressing their own opinions. Some emphasized the relation of mathematics to real situations (practical category) by mentioning examples of their personal experience. One person named interactionism (social category) as a collective construction of knowledge (concept absent in the proposed readings). We emphasize that only two participants made observations that explicitly related several approaches and, in both cases, happened in relation to an educational problem. One person observed that different guilds (doctors and psychologists) use different mathematics according to the contextual needs of their profession. Another showed that the social construction of mathematics is linked to situations 
that arise in concrete contexts and suggested to take advantage of them to stimulate students' interest in what mathematics are useful for.

We emphasize that only a few participants, who had already come up with concerns from previous experiences, made deep observations and expressed doubts, criticisms, or personal comments to the proposed documents.

\subsection{Final debate}

Figure 3 shows that the final debate was much richer.

\begin{tabular}{|c|c|c|c|c|c|c|c|c|c|c|c|c|c|c|}
\hline Code System & Di & Mar & De & Ga & Ru & Ve & Mat & El & Va & Jo & Ka & $\mathrm{Da}$ & Je & Ta \\
\hline 트 Scholar mathematics & & & & & & & & 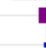 & & & & & & \\
\hline E Doubt & & . & & 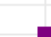 & & & $\mathbf{E}$ & & & & & & & \\
\hline E Who decides & & $\theta^{\circ}$ & & . & & . & & & & & & & & \\
\hline $\begin{array}{l}\text { E E Practical } \\
\text { E Social }\end{array}$ & & & & 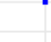 & & : & & & & & & & & \\
\hline 트 Cultural & & & & & & & & & & & & & & \\
\hline
\end{tabular}

Figure 3 - Code matrix for final debate, generated by MAXQDA7. The size of the marks in the cells depends on the frequency of the codes.

Source: Elaborated by the authors

Here, codes related to the emergence of doubts show the clash between participants' previous understanding and the approaches introduced with the workshop (COONEY, 2001). One teacher strongly advocated focusing on school mathematics. Several participants $(8 / 14)$, in contrast to this comment, considered that mathematics are somewhat more about the school-academic conception and goes beyond concepts. Someone explicitly asked the question: what is math? This issue brought forward the problem, highlighted by some $(5 / 14)$, of who decides whether in a given practice there is mathematics. Furthermore, they highlighted the question of what authority determines it, whether the community itself or an external observer. These same questions appear in the theoretical literature of ethnomathematics and were answered in many ways (ROSA; OREY, 2007; BARTON, 2008; ALBANESE; PERALES, 2014).

Finally, two observations emphasized mathematics as an instrument to systematize experience and solve real problems (practical category). Whereas two others insisted that ideas arise in interaction and agreement is needed (social category). There were no comments on the cultural category, despite being the most present in the initial debate. The cultural approach seems to have been perceived but not internalized by the participants. 


\subsection{Open questionnaire}

In Frame 3, we summarize the inductive codes obtained in the analysis of the responses to the final questionnaire, distributed by item and category.

\begin{tabular}{|llllll|}
\hline Item & $\begin{array}{l}\text { 1. Mathematical } \\
\text { thinking }\end{array}$ & $\begin{array}{l}\text { 2. Mathematical } \\
\text { nature }\end{array}$ & $\begin{array}{l}\text { 3. Aspects of } \\
\text { ethnomathematics }\end{array}$ & $\begin{array}{l}\text { 4. } \\
\text { Methodology }\end{array}$ & 5. Usefulness \\
\hline Practical & $\begin{array}{l}\text { Modeling real } \\
\text { situations }\end{array}$ & $\begin{array}{l}\text { Modeling of daily } \\
\text { patterns }\end{array}$ & $\begin{array}{l}\text { Experience/research } \\
\text { Practical } \\
\text { mathematics }\end{array}$ & $\begin{array}{l}\text { Concrete } \\
\text { experience } \\
\text { Motivating }\end{array}$ & $\begin{array}{l}\text { Daily for } \\
\text { school work } \\
\text { Math for real- } \\
\text { life situations }\end{array}$ \\
\hline Social & Agreement & Social Construct & $\begin{array}{l}\text { Collective and } \\
\text { consensus }\end{array}$ & Group & $\begin{array}{l}\text { Social } \\
\text { interactions }\end{array}$ \\
\hline Cultural & & Other math & Different math & $\begin{array}{l}\text { Different point } \\
\text { of view }\end{array}$ & $\begin{array}{l}\text { Different } \\
\text { thinking }\end{array}$ \\
\hline
\end{tabular}

Frame 3 - Inductive codes (in italics) obtained from the answers to the questionnaire items and their relationship with the established categories

Source: Elaborated by the authors.

As an example of the coding process followed, we show the process for the second item.

Item 2: What implications on the nature of mathematics does this activity entail?

JO: This activity clearly shows the potential of mathematics to modernize everyday facts.

MAR: Mathematics arises as a need to systematize a concrete practice and, at the same time, allows us to imagine other twisted ones. (Data from the questionnaire)

These two participants demonstrated the role of mathematics as the generator of models to understand and control situations of everyday life (e.g., inventing new braid patterns). We assigned them the code "Modeling of daily patterns" and placed them into the practical category.

VAN: Through this activity, we were able to perform a case analysis and generated patterns to perform a modeling and generalization on braid assembly ...

JE: Mathematics tries (in part) to create representations of a part of reality and its internal relations (or some of them) and from that model we generate new knowledge about that portion of reality. (Data from the questionnaire)

These two participants went a little further, both recognizing that mathematics is a tool to model reality but also insisting on detecting internal relationships and patterns. We encoded these observations as "patterns" and we also considered them in the practical category.

KA: Mathematics is a socially constructed science. (Data from the questionnaire)

This participant made explicit the key point of the social approach, the social construction.

DI...I wonder, what is math? Reflecting on transformations throughout history and opening up to new transformations. (Data from the questionnaire)

The next one solved its dilemma about the nature of mathematics in the historical sense, looking at the transformation of mathematics over time. We associated this observation 
with the idea that mathematics is a historical product and we assigned it to the social category.

MAT: Mathematics is more about school mathematics or academic mathematics.

$V E$ : The arbitrariness of notions, the coexistence of some representations (over others), the relationship of that coexistence with the particular reading of each of those who uses that representation. (Data from the questionnaire)

These last two observations showed the existence of different ways of doing mathematics with respect to the academic and different points of view of the same problem (elaboration of diverse notations), respectively. In addition, they showed the particularity in the interpretation of the same representation depending on the observer. The other mathematics answers were related to the existence of different mathematics and we assigned them to the cultural approach.

We now synthesize in Figure 4 the overall results of the group of participants using inductive codes developed according to each item of the questionnaire. It is worth mentioning that the category indicated with the dotted frame cells is not considered in this analysis, it is actually related to the static view of the conceptions about the nature of mathematics mentioned in the theoretical framework (section 2).

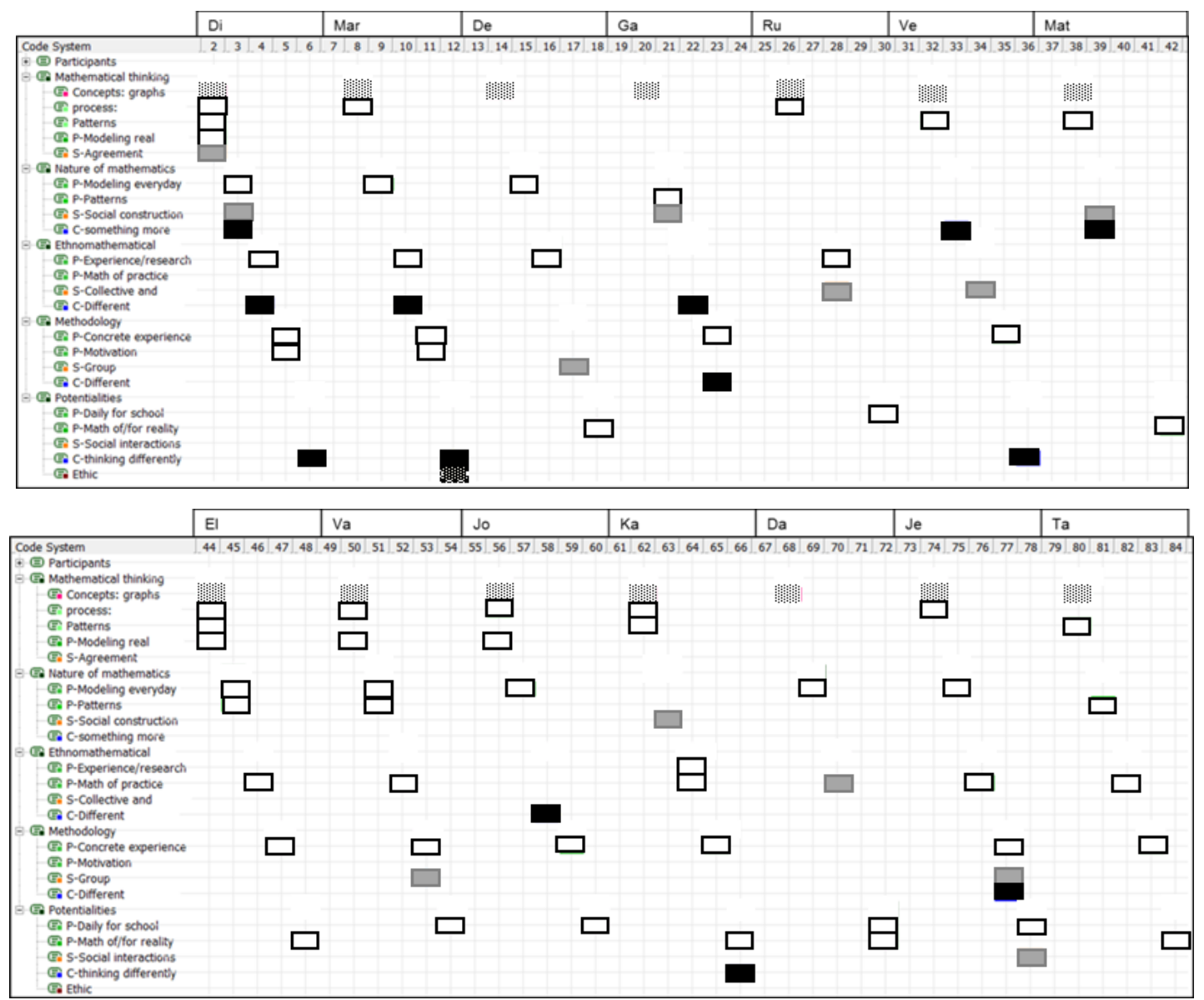

Figure 4 - Code delineator generated by the MAXQDA7 for the answers to the final open questionnaire grouped by item. Note that each cell is associated with a color corresponding to the category, white for practice, gray for social, black for cultural. Dotted frame cells are not associated with any category (static view). Source: Elaborated by the authors 
Item 1: What mathematical thinking have you used in making, representing, and inventing braids?

The 14 participants began by enumerating mathematical concepts: graphs and combinatorial elements as permutations (cells with dot-plot). But only three of them were limited to that. The other 11 then referred to processes such as generalization, modeling, systematization (8/14), and the recognition and application of patterns, relationships and regularities. In both cases a connection with the real world was implicit, but there were four of these participants that explicitly referred to mathematics as a tool for modeling a real situation and predicting the behavior of more general cases (practical category). We highlighted a single observation that showed the social category, indicating the importance of establishing an agreement on representations.

Item 2: What implications does this activity entail regarding the nature of mathematics?

Ten participants of the 14 who answered this question observed that the activity highlights the importance of mathematics to model everyday situations, represent reality, and also recognize and control relationships and patterns to handle general cases (practical category). Four participants highlighted the social category of mathematics describing them as a socially constructed science, intrinsic to human activity, transformed throughout history, and recognizing the role of institutions in indicating where mathematics exists. Finally, three participants showed evidence of the cultural category: two indicated that we need to consider something more than school and classical mathematics, and one insisted on the coexistence of different representations by valuing each one's way of thinking.

Item 3: What aspects of ethnomathematics have you worked on?

Ten of the 14 participants answered this question. As elements of ethnomathematics, with respect to the practical category, direct experience, and research (five of them) stood out from the concrete element to demonstrate the ability of mathematics to reflect on reality (six of them). Two responses pointed to the social category, valuing work in small groups and collective construction through consensus. Finally, in four of the answers there was evidence of the cultural category in terms of the existence of other non-scholarly but equally useful knowledge linked to practices developed in certain cultures according to their needs and traditions.

Item 4: Do you consider that you have experienced an enculturation process? What aspects of the experience did you find relevant in relation to the work methodology?

Ten of the 11 answers to this question focused on the importance of the practical 
category: starting from the concrete towards a practical and real experience - making braids then putting themselves in the place of the artisans. Two participants also highlighted the strong motivating component of the experience. Three reflected on the weight of the interpersonal character of small-group work and the construction of a consensus (social category). Two answers referred to the cultural category recognizing the valuation of the existence of diverse points of view and different ways of constructing knowledge.

Item 5: What educational potential do you see in this type of work?

We highlight the variety of observations that characterize the 13 responses to this question. Of the 10 that insisted on the practical category, we recognized two lines of thought: five answers pointed to the possibility of starting from a practical theme and various concrete situations to introduce school subjects. Six answered (in one case the two codes are both present) indicating the potential of this type of activity to present mathematics as really useful in everyday situations and to evidence the intrinsic nature of mathematics in certain concrete practices. A single participant valued the potentials of social interactions (social category) and four commented on the cultural category: the importance of learning to think differently (open mind), appreciating the variety of emerging ideas and disrupting the way of presenting class. Finally, we highlight the ethical formulation of a response that indicates this activity as a means of inclusion for minority cultures.

In general, the codes of the social and cultural categories were much less present than those of the practical category (Figure 4). Furthermore, when returning to the answers they showed that, especially, the cultural approach is always indirectly manifested in observations. This indicates that these ideas were delineated but never fully developed.

We emphasize the strong presence of codes of the practical category found in all the participants, as initially hypnotized and we noticed the balance of appearance of the social and cultural categories. This contrasted with our initial theoretical analysis where we suggested a subordination of the social approach to the cultural approach.

\subsection{Profile description}

As evidence of the social and cultural approaches, we grouped the participants into profiles according to their conceptions considering that more complex and articulated conceptions are desirable in pre-service teachers.

The proposed profiles are described in Frame 4. 


\begin{tabular}{|c|c|c|c|c|}
\hline & Profile 1 & Profile 2 & Profile 3 & Profile 4 \\
\hline 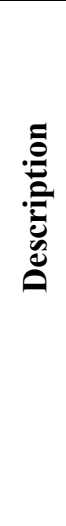 & $\begin{array}{l}\text { They show much } \\
\text { evidence of the } \\
\text { practical } \\
\text { approach; } \\
\text { however they lack } \\
\text { the recognition of } \\
\text { the others, or have } \\
\text { not fully accepted } \\
\text { them. }\end{array}$ & $\begin{array}{l}\text { Questions arise } \\
\text { over the academic } \\
\text { conception of math } \\
\text { and there is an } \\
\text { initial acceptance of } \\
\text { the social and } \\
\text { cultural approaches. } \\
\text { However, these are } \\
\text { simply outlined. }\end{array}$ & $\begin{array}{l}\text { They express doubts and } \\
\text { raise questions about the } \\
\text { search for something } \\
\text { more in their } \\
\text { understanding of } \\
\text { mathematics. They } \\
\text { integrate theoretical } \\
\text { notions with practical } \\
\text { experience, solving the } \\
\text { concerns generated to } \\
\text { formulate educational } \\
\text { implications of the new } \\
\text { approaches. }\end{array}$ & $\begin{array}{l}\text { They present } \\
\text { relativistic } \\
\text { conceptions that seem } \\
\text { to have been settled } \\
\text { from before. There is } \\
\text { a high level of } \\
\text { interiorization of the } \\
\text { three approaches that } \\
\text { are shown to be } \\
\text { deeply articulated } \\
\text { between them. }\end{array}$ \\
\hline
\end{tabular}

Frame 4 - Description of profiles according to the conceptions about the nature of mathematics. Source: Elaborated by the authors

We then assigned and described the participants' location in these profiles:

Profile 1: Two participants presented this profile (TA and $E L)$. In their answers, they manifested only codes of the practical category. We highlight the case of EL who seems to reject the social and cultural approaches, in fact absent in his questionnaire, despite the initial concern about the educational implications related to the social approach. His intervention in the debate was in favor of recognition just of academic mathematics.

Profile 2: Six participants present in the final classification categories related to the doubts and hardly outlined the social or cultural approaches in the questionnaire answers. It is important to remember that doubt is a fundamental element to generate reflection and, eventually, changes (COONEY, 2001).

Profile 3: Three participants $(M A R, J E, K A)$ in the debate recognized that mathematics go beyond academics and they present observations related to social and/or cultural categories in two responses to the questionnaire and -except one- presented both categories. Here the manifested doubts reflect a deeper reflection than the previous profile.

Profile 4: Three participants made observations on social and cultural approaches in three or more responses. During the debate, they generated the dilemma about who decides what is, or is not, mathematics and this showed a good internalization of the relativist positions. In the answers to the questionnaire, a high articulation of the three approaches was detected; in addition, the categories were well interrelated. Two of these answers came from people $(V E, D I)$ whose experience and reflection were very deep according to their trajectory. However, it is important to highlight the case of $G A$ that in the final debate and in the questionnaire answers insisted on the different points of view determined by culture and environment. 


\section{Final reflection}

We consider that the initial objective of describing and analyzing the conceptions about the nature of mathematics has been fulfilled. For this, it has been fundamental to define the practical, social, and cultural approaches of ethnomathematics through a dialogical process between the theory and the analysis carried out, providing us with the tools to interpret the data and allowing us to describe almost all the participants' answers.

The categories associated with such approaches emerged from the research process but with substantial roots in the theory, constituting a powerful tool of organization and interpretation of the mathematics conceptions from an ethnomathematical perspective. Conversely, we succeeded in grouping such conceptions according to their proximity to desirable conceptions. An unexpected outcome was the balance in the appearance of the social and cultural approaches.

The workshop on (ethno)modeling braiding has proved to be a fruitful environment for participants to become aware of and make observations that demonstrate their understanding of what is mathematics. The debates have been an important learning moment for all the participants who became aware of the diversity and richness of their conceptions. The results have shown the complexity of interpreting epistemological conceptions.

Time constraints do not allow to affirm if there was a proper change in the participants' conceptions. Yet, this research contributes to show that ethnomathematical workshops based on ethno-modeling are a favorable environment to bring out and reflect on sociocultural nuances in the conceptions on the nature of mathematics and contributes to the Ethnomathematical Program by providing a model of interpretation of the conceptions that enrich the previous existing ones allowing to analyze such sociocultural nuances.

In spite of the limitations inherent in an exploratory and qualitative study such as this one, we believe that it constitutes a significant precedent for those who intend to study the conceptions on the nature of mathematics from an ethnomathematical perspective and it can constitute a good starting point to identify the epistemological conceptions about mathematics that ethnomathematics implies.

As a future perspective, we are challenged to follow up on how teachers transfer their conceptions in their classrooms. 


\section{Acknowledges}

We thank the Spanish Ministry of Education that made this research possible through a FPU grant (AP2010-0235) to Veronica Albanese of the University of Granada.

\section{References}

ALBANESE, V., Y PERALES, F. J. Una experiencia en la formación de profesores sobre concepciones desde una perspectiva Etnomatemática. UNIÓN, Revista Iberoamericana de Educación Matemática, San Cristóbal de La Laguna, n. 49, p. 73-83, abr. 2017.

ALBANESE, V.; ADAMUZ-POVEDANO, N.; BRACHO-LOPEZ, R. Ethnomathematics: two theoretical views and two approaches to education. In: Rosa, M.; Shirley, L.; Gavarrete, M. E.; Alangui, W. (Eds.). Ethnomathematics and its Diverse Approaches for Mathematics Education. Berlin: Springer, 2017. p. 307-328.

ALBANESE, V.; PERALES, F. J. Pensar matemáticamente: una visión etnomatemática de la Práctica artesanal soguera. RELIME - Revista latinoamericana de investigación en matemática educativa, Mexico DF, v. 17, n. 3, p. 261-288, nov. 2014.

ALBANESE, V.; OLIVERAS, M. L.; PERALES, F. Etnomatemáticas en artesanías de trenzado: aplicación de un modelo metodológico elaborado. BOLEMA - Boletim de Educação Matemática, Rio Claro, v. 28, n. 48, p. 1-20, abr. 2014.

ALBANESE, V.; SANTILLÁN, A.; OLIVERAS, M. L. Etnomatemática y formación docente: el contexto argentino. Revista Latinoamericana de Etnomatemática, San Juan de Pasto, v. 7, n. 1, p. 198-220, abr. 2014.

ALBANESE, V.; OLIVERAS, M. L.; PERALES, F. Modelización matemática del trenzado artesanal. Revista Épsilon, Córdoba (España), v. 29, n. 81, p. 53-62, dic. 2012.

BARTON, B. Ethnomathematics and Philosophy. In: FORGASZ, H.; RIVERA, F. D. (Ed.). Towards Equity in Mathematics Education: Gender, Culture, and Diversity. Berlin: Springer, 2012. p. 231240.

BARTON, B. Making sense of ethnomathematics: Ethnomathematics is making sense. Educational Studies in Mathematics, Dordrecht, v. 31, n. 1, p. 201-233, sep. 1996.

BARTON, B. The language of mathematics: Telling mathematical tales. Melbourne: Springer, 2008.

BISHOP, A. J. Enculturación Matemática. Barcelona: Paidós, 1999.

CABRERA, I. El análisis de contenido en la investigación educativa: propuesta de fases y procedimientos para la etapa de evaluación de la información. Pedagogía Universitaria, Huelva, v. 14, n. 3, p. 71-93, oct. 2009.

CHARALAMBOUS, C. Y.; PANAOURA, A.; PHILIPPOU, G. Using the history of mathematics to induce changes in preservice teachers' beliefs and attitudes: Insights from evaluating a teacher education program. Educational Studies in Mathematics, Dordrecht, v. 71, n. 2, p. 161, jun. 2009.

COONEY, T. J. Considering the paradoxes, perils, and purposes of conceptualizing teacher development. In: LIN, F. L.; COONEY, T. J. (Ed.). Making sense of mathematics teacher 
education. Dordrecht: Kluwer Academic, 2001. p. 9-13.

CROSS, D. I. Alignment, cohesion, and change: Examining mathematics teachers' belief structures and their influence on instructional practices. Journal of Mathematics Teacher Education, Hidelberg, v. 12, n. 5, p. 325-346, oct. 2009.

D'AMBROSIO, U. Etnomatemática: Eslabón entre las tradiciones y la modernidad. México: Limusa, 2008.

D'AMBROSIO, U. Ethnomathematics and its place in the history and pedagogy of mathematics. For the learning of Mathematics, Fredericton, v. 5, n. 1, p. 44-48, feb. 1985.

DE GUARDIA, J. A. Cuestiones del folklore. Patrimonio cultural folklórico: perspectivas para su entendimento. Salta: Editorial Portal de Salta, 2013.

DIONNE, J. J. The perception of mathematics among elementary school teachers. In: MOSER, J. M. (Ed.). Proceedings of the 6th conference of the North American chapter of the international group for the psychology of mathematics education. Madison: University of Wisconsin-Madison, 1984. p. 223-228.

ERNEST, P. The impact of beliefs on the teaching of mathematics. In: ERNEST, P. (Ed.). Mathematics teaching: The state of the art. New York: Falmer Press, 1989. p. 249-254.

FELBRICH, A.; KAISER, G.; SCHMOTZ, C. The Cultural Dimension of Beliefs: An Investigation of Future Primary Teachers' Epistemological Beliefs Concerning the Nature of Mathematics in 15 Countries. In: BLÖMEKE, S.; HSIEH, F.; KAISER, G.; SCHEMINDT, W (Ed.). International Perspectives on Teacher Knowledge, Beliefs and Opportunities to Learn. Dordrecht: Springer, 2014. p. 209-229.

FELBRICH, A.; MÜLLER, C.; BLÖMEKE, S. Epistemological beliefs concerning the nature of mathematics among teacher educators and teacher education students in mathematics. ZDM, Berlin, v. 40, n. 5, p. 763-776, dec. 2008.

GAVARRETE, M. Matemáticas, Culturas y Formación de Profesores en Costa Rica. 2013. 734 f. Tesis (Doctorado en Ciencia de la Educación) - Departamento de Didáctica de la Matemática, Facultad de Educación, Universidad de Granada, Granada, 2012.

GERDES, P. On culture and mathematics teacher education. Journal of Mathematics Teacher Education, Hidelberg, v. 1, n. 1, p. 33-53, jan. 1998.

GOLDIN, G.; RÖSKEN, B.; TÖRNER, G. Beliefs-No longer a hidden variable in mathematical and learning processes. In: SCHLÖGLMANN W.; MAASZ, J. (Ed.). Beliefs and attitudes in mathematics education: New research results. Rotterdam: Sense Publishers, 2009. p. 1-18.

GRIGUTSCH, S.; RAATZ, U.; \& TÖRNER, G. Einstellungen gegenüber Mathematik Bei Mathematiklehrern. Journal für Mathematik-Didaktik, Berlin, v. 19, n. 1, p. 3-45, dec. 1998.

KNIJNIK, G. Differentially positioned language games: ethnomathematics from a philosophical perspective. Educational Studies in Mathematics, Dordrecht, v. 80, n. 1-2, p. 87-100, may. 2012.

LILJEDAHL, P.; OESTERLE, S.; BERNÈCHE, C. Stability of beliefs in mathematics education: a critical analysis. Nordic Studies in Mathematics Education, Gothenburg, v. 17, n. 3-4, p. 101-118, dec. 2012.

LILJEDAHL, P.; ROLKA, K.; ROESKEN, B. Affecting affect: the reeducation of preservice teachers' 
beliefs about mathematics and mathematics teaching and learning. In: MARTIN, W. G.;

STRUTCHENS, M. E.; ELLIOTT, P. C. (Ed.). The Learning of Mathematics: Sixty-Ninth Yearbook of the National Council of Teachers of Mathematics. Reston: National Council of Teachers of Mathematics, 2007. p. 319-330.

NARESH, N. The role of a critical ethnomathematics curriculum in transforming and empowering learners. Revista Latinoamericana de Etnomatemática, San Juan de Pasto, v. 8, n. 2, p. 450-471, abr. 2015.

NOLAN, K.; GRAHAM, S. Challenging teachers' perceptions of what mathematics is: Reflecting on culturally responsive pedagogy (CRP) in the mathematics classroom. In: INTERNATIONAL CONGRESS OF ETHNOMATHEMATICS (ICEM6), 6, 2018, Medellin. Proceedings... Medellin: Universidad de Antioquia, 2018. p. 21.

OLIVERAS, M. L.; ALBANESE, V. Etnomatemáticas en Artesanías de Trenzado: Un Modelo Metodológico para Investigación. BOLEMA - Boletim de Educação Matemática, Rio Claro, v. 26, n. 44, p. 1295-1324, dic. 2012.

OLIVERAS, M. L. Etnomatemáticas: Formación de profesores e innovación curricular. Granada: Comares, 1996.

PAJARES, M. F. Teachers' beliefs and educational research: Cleaning up a messy construct. Review of Educational Research, Newbury Park, v. 62, n. 3, 307-332, sep. 1992.

PONTE, J. P.; CHAPMAN, O. Mathematics Taecher's Knowledge and Practice. In: GUTIÉRREZ, A.; BOERO, P. (Ed.). Handbook of Research on the Psychology of Mathematics Education: past, present and future. Rotterdam: Sense, 2006. p. 461-494.

PRESMEG, N. Beliefs about the nature of mathematics in the bridging of everyday and school mathematical practices. In: LEDER, G.; PEHKONEN, E.; TORNER, G. (Ed.). Beliefs: A hidden variable in mathematics education? New York: Kluwer Academic, 2002. p. 293-312.

PRESMEG, N. Ethnomathematics in Teacher Education. Journal of Mathematics Teacher Education, Hidelberg, v. 1, n. 3, p. 317-339, oct. 1998.

ROSA, M.; OREY, D. C. A modelagem como um ambiente de aprendizagem para a conversão do conhecimento matemático. Bolema, Rio Claro, v. 26, n. 42, p. 261-290, abr. 2012.

ROSA, M.; OREY, D. C. Cultural assertions and challenges towards pedagogical action of an ethnomathematics program. For the Learning of Mathematics, New Brunswick, v. 27, n. 1, p. 10-16, mar. 2007.

SHIRLEY, L. Ethnomathematics as a fundamental of instructional methodology. ZDM, Berlin, v. 33, n. 3, p. 85-87, jun. 2001.

TÖRNER, G.; GRIGUTSCH, S. 'Mathematische Weltbilder' bei Studienanfängern - eine Erhebung. Journal für Mathematik-Didaktik, Berlin, v. 15, n. 3/4, p. 211-251, dec. 1994.

WOODS, P. La escuela por dentro. Barcelona: Paidós, 1987.

Submetido em 22 de Abril de 2019. Aprovado em 21 de Outubro de 2019. 